\title{
Comparison of Performance of an Intermittent Aeration Membrane Bioreactor and a Conventional Activated-sludge System in the Treatment of Palm Oil Mill Effluent
}

\author{
S. Annop' 1 P. Sridang ${ }^{2 *}$, P. Chevakidagarn ${ }^{3}$ \& K. Nopthavorn ${ }^{4}$ \\ ${ }^{1 \& 3}$ Faculty of Environmental Management, Prince of Songkla University (PSU), Songkhla 90112, Thailand \\ ${ }^{2 \& 4}$ Department of Civil lingincering. Membrane Science and Technology Research Center (MSTRC), Prince of \\ Songkla University 90112, Thailand
}

\begin{abstract}
The main objective was to compare the performances and the removal efficiencies of two biological treatment systems, a submerged membrane bioreactor (SMBR) and a simultaneous activated sludge (AS), for treating Palm Oil Mill Effluent (POME). Tivo lab scale units of SMBR and AS with a working volume of $24 \mathrm{~L}$ were operated under favorable biological conditions and minimized membrane fouling intensity. To achieve both carbonaceous and nitrogen removal, the cyclic air intermittent and dissolved oxygen control were performed into SMBR and AS with the influent flow rate about $16 \mathrm{~L} / \mathrm{d}$ respectively. In terms of organic removal and membrane performance, the SMBR showed good removal efficiency to treat high strength wastewater with organic loading variation of POME. The average removal rates of TCOD, BOD, Turbidity, Color, Oil and Grease, $\mathrm{NH}_{3}-\mathrm{N}$, TKN were $69 \pm 2,76 \pm 2$, $100 \pm 1,37 \pm 21,92 \pm 6,67 \pm 4$ and $75 \pm 10 \%$ respectively. Results pointed out the benefit of membranes retained totally the active compositions of biomass in each stage of development. The AS showed the limitation of sedimentation phase for sludge and oil separation. The characteristics of sludge in SMBR showed healthy floc formations and good settling after $240 \mathrm{~h}$. The concentrations of COD and BOD in permeate were around $870 \pm 53$ and $37 \pm 13$ $\mathrm{mg} / \mathrm{L}$.
\end{abstract}

Keywords: MBR, palm oil mill effluent, performance and efficiency, fouling, intermitten aeration

\subsection{INTRODUCTION}

The oil palm industry is one of the most important industries in Thailand because its outcomes can be used as raw material for producing various products. In recently years, oil palm has been supported as a source of renewable energy, biodiesel, by the Thai Government. Therefore, rapid increase of the cultivated area of palm trees is still promoted. However, a large amount of crude Palm Oil Mill Effluent (POME) is discharged from palm oil mill industries. POME is generated from three major sources, namely sterilizer condensate, hydrocyclone waste and separator

*Correspondence to: P. Sridang (email: porntip.c@psu. ac.th) sludge [1]. It is reported crude palm oil produced, about 2,500-3,500 $\mathrm{kg}$ of POME is generated. POME is rich organic carbon, BOD higher than $20 \mathrm{~g} / \mathrm{L}$, nitrogen content around $0.2 \mathrm{~g} / \mathrm{L}$ as ammonia nitrogen and $0.5 \mathrm{~g} / \mathrm{L}$ total nitrogen [2]. POME also has high turbidity, color, suspended solids and oil and grease [3]. Reports state that comparing POME with domestic wastewater ( $60 \mathrm{~g} \mathrm{BOD/capita/d)} \mathrm{showed} \mathrm{that} \mathrm{POME} \mathrm{has} \mathrm{a}$ significant impact on organic loading and is discharged by about 3 million people [4]. The palm oil mill industry in Thailand was identified as the one that produces the largest pollution load into rivers, as is the case in nearby countries.

Several of the biological processes in anaerobic and aerobic conditions are well performed, such 
as the conventional activated-sludge (AS) process, the anaerobic digester, and the pond system. However, the quality of effluent still does not pass the Thai Standard for effluent due to the complexity of its characteristics and also the limitation of each selected process. The MBR process has become increasingly popular in the field of wastewater treatment; the MBR is used as a modification of AS, where the traditional secondary clarifier is replaced by a membrane unit for the separation of treated water from the mixed solution in the bioreactor [5]. MBR technology has many advantages: high treated water quality, retention of all suspended solids and microorganisms, and absolute control of biomass and hydraulic retention time [6]. This system can operate in various conditions. Recent studies have introduced alternating aerobic and anaerobic conditions in MBR by intermittent aeration for simultaneous removal of carbon and nitrogen [7]. However, previous studies mainly focused on performance in the removal of carbon and nitrogen, but there is little research focusing on and comparing the performance of MBR and AS systems to treat real POME in similar conditions.

The objective of this study was to compare the performance of MBR and AS system for removing both of nitrogenous and carbonaceous substances, in which the MBR under study was operated under intermittent aeration and AS was operated simultaneously by control aeration rate.

\subsection{METHODS/THEORY}

\subsection{Experimental Set-up and Operation}

The experiments were carried out in laboratory scale MBR and AS units. A detailed schematic of the pilot-scale MBR system is presented in Figure 1. The membrane module used was a hollow fiber membrane module, made from Polyethylene-Hydrophilic Polymer Membrane, with a pore size of $0.22 \mu \mathrm{m}$ and a filtration area of $0.2 \mathrm{~m}^{2} /$ module. The hollow fiber membrane module was directly submerged in the reactor, in which the aeration system was installed under the module providing air bubbling close to the fiber network. The operating conditions

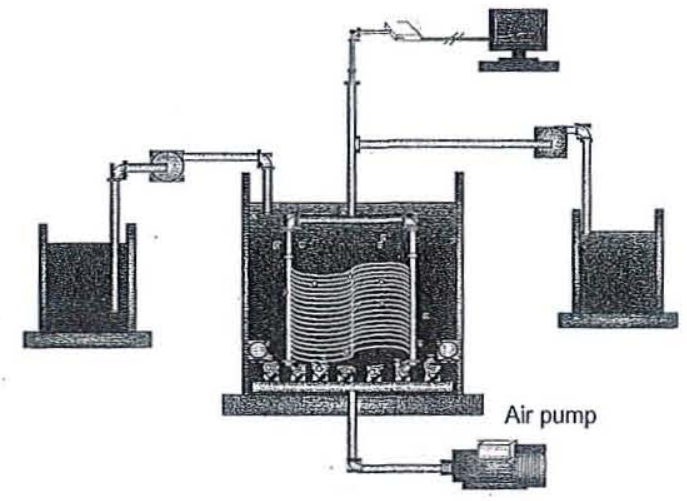

Figure 1 Schematic of the pilot-scale MBR system $(1=$ substrate feeding tank, $2=$ MBR with air bubbling system, $3=$ permeate tank, 4 = the pressure sensor)

summarized in Table.1. The solid accumulation and biomass on the membrane surface were controlled and related by a sheering streșs from bubbles turbulence. The pressure sensor was installed to monitor the variation in the transmembrane pressure (TMP). In the MBR the system was operated at a $3 \mathrm{~h} /$ cycle $(8$ cycles/d) under the following intermittent aeration: (1) 'POME was fed to the reactor during the anoxic phase for $15 \mathrm{~min}$; (2) in the reactor; anoxic phase for $2 \mathrm{~h}$ and aerobic phase for $1 \mathrm{~h}$; and (3) the discharging of treated wastewater (permeate) took place during the aeration phase for $1 \mathrm{~h}$. All

Table 1 Summarry of MBR and AS operating conditions

\begin{tabular}{lcc}
\hline Conditions & $\begin{array}{c}\text { Values } \\
\text { MBR }\end{array}$ & AS \\
\hline Temperature $\left({ }^{\circ} \mathrm{C}\right)$ & $25-36$ & $25-36$ \\
$\mathrm{pH}$ & $7.15-7.45$ & $7.15-7.45$ \\
Working volumn $(\mathrm{L})$ & 24 & 24 \\
Feeding volumn $(\mathrm{L} / \mathrm{d})$ & 16 & 16 \\
F/M (kg COD/kg MLVSS d) & 0.15 & 0.49 \\
HRT (h) & 36 & 36 \\
SRT (day) & 100 & 5 \\
Air flow rate $(\mathrm{L} / \mathrm{min})$ & 10 & 3 \\
Dissloved oxygen $(\mathrm{mg} / \mathrm{L})$ & $5-7$ & $1.10-1.30$ \\
Permeate flux $\left(\mathrm{L} / \mathrm{hr} / \mathrm{m}^{2}\right)$ & 10 & - \\
TMP limitation $(\mathrm{mbar})$ & 500 & - \\
\hline
\end{tabular}


conditions were controlled by a timer-controlled power supply. To avoid over fouling of the membrane the limitation of TMP was controlled and the cleaning processes. The specific cleaning steps were different in the hydrodynamic and chemical methods: rinsing with water, backwashing with water, immersed and backwashing with $1 \% \mathrm{w} / \mathrm{v}$ citric acid at flux $10-12 \mathrm{~L} / \mathrm{h} / \mathrm{m}^{2}$ for $1 \mathrm{~h}$, immersed and backwashing with $1 \% \mathrm{w} / \mathrm{v}$ caustic at flux $14-16 \mathrm{~L} / \mathrm{h} / \mathrm{m}^{2}$ for $2 \mathrm{~h}$ and immersed in sodium hypochlorite $1 \% \mathrm{w} / \mathrm{v}$ cleaning for $2 \mathrm{~h}$. The permeability of water was measured after each cleaning step. The origin and potential of membrane fouling can be identified if the causes are present.

The AS system was operated continuously, and the aeration system was installed under the aeration tank. The operating conditions summarized in Table 1. The concentration of liquor mix with volatile suspended solids (MLVSS) was kept and maintained at nearly $4,000 \mathrm{mg} / \mathrm{L}$ after the steady state condition.

\subsection{Raw Wastewater and Seed Sludge}

Both the MBR and AS systems were used for the same feed source of POME. This came from a grease trap and anaerobic pond of a palm oil mill wastewater treatment plant. The POME feed was obtained from the oil palm mill industry in Hat
Yai district of Songkhla province. The characteristics of the wastewater used are summarized in Table 2. The seed sludge was obtained from a sludge recirculation line of an AS treatment plant of a concentrated rubber industry plant in Songkhla. The period of sludge assimilation feeding with POME was done with the beginning of the sludge concentration in both reactors at about 3,000 mg/L MLSS which was in the normal criteria range of MLSS designing for activated sludge process.

\subsection{Analytical Methods}

The efficiency and performance of MBR and AS systems were investigated according to the daily measurements of $\mathrm{pH}$, dissolved oxygen and temperature. The SS, $\mathrm{NH}_{3}{ }^{-} \mathrm{N}, \mathrm{TKN}, \mathrm{COD}$, Oil and Grease, Turbidity, Color, MLSS, MLVSS and BOD in influent and effluent were analyzed three times a week while the biodegradable organic content in the BOD was done once a week. The permeate and effluent were analyzed for the nitrogen compounds in term of $\mathrm{NO}_{3}$ and $\mathrm{NO}_{2}$. All parameters followed standard methods [8]. The particle size distribution, using a Laser Particle Size Analyzer (COULTER LS230), was also studied. The structure of biomass and its population in the MBR and AS systems were analyzed using an optical microscope.

Table 2 Performance summary of MBR and AS systems

\begin{tabular}{lccccc}
\hline Parameter & Wastewater & $\begin{array}{c}\text { MBR } \\
\text { permeate }\end{array}$ & $\begin{array}{c}\text { AS } \\
\text { effluent }\end{array}$ & $\begin{array}{c}\text { Removal } \\
\text { Efficiency } \\
(\%) \text { in MBR }\end{array}$ & $\begin{array}{c}\text { Removal } \\
\text { Efficiency } \\
\text { (\%) in AS }\end{array}$ \\
\hline $\mathrm{COD}, \mathrm{mg} / \mathrm{L}$ & $\cdot$ & & & 69 & 54 \\
$\mathrm{BOD}, \mathrm{mg} / \mathrm{L}$ & $1495 \pm 77$ & $870 \pm 53$ & $1316 \pm 144$ & 76 & 48 \\
$\mathrm{SS}, \mathrm{mg} / \mathrm{L}$ & $1625 \pm 989$ & $\mathrm{ND}$ & $1019 \pm 706$ & 100 & 61 \\
Turbidity,NTU & $1015 \pm 526$ & $2.2 \pm 0.8$ & $347 \pm 80$ & 99.7 & 37 \\
Color, Su & $201 \pm 44$ & $120 \pm 38$ & $145 \pm 38$ & 37 & 25 \\
Oil and Grease, mg/L & $496 \pm 346$ & $25 \pm 24$ & $142 \pm 136$ & 92 & 42 \\
$\mathrm{TKN}, \mathrm{mg} / \mathrm{L}$ & $372 \pm 47$ & $93 \pm 34$ & $199 \pm 16$ & 75 & 48 \\
$\mathrm{NH}_{3}{ }^{-\mathrm{N}}, \mathrm{mg} / \mathrm{L}$ & $213 \pm 63$ & $69 \pm 20$ & $134 \pm 16$ & 67 & 43 \\
$\mathrm{NO}_{2}, \mathrm{mg} / \mathrm{L}$ & $\mathrm{ND}$ & $13 \pm 10$ & $2 \pm 3$ & - & - \\
$\mathrm{NO}_{3}, \mathrm{mg} / \mathrm{L}$ & $\mathrm{ND}$ & $32 \pm 23$ & $11 \pm 6$ & - & - \\
\hline
\end{tabular}

All analyses were COD performed over a steady-state period 16 days

All analyses were COD performed over a steady-state period 14 days

ND non detectable (lower than detection limit value) 


\subsection{RESULTS AND DISCUSSIONS}

\subsection{Biomass Growth and Characteristics}

The biomass characteristics in the MBR and AS systems were investigated and their development followed up, thus determining the biomass concentration (MLSS and MLVSS). The results showed the rapid increase of biomass at the beginning of the phase in each start up period of the MBR and AS systems. It was found that the steady state condition was reached after 18 days for the MBR and after 15 days for the AS. The concentration of MLSS and MLVSS in MBR was higher 2 times than in AS studied at the steady state condition. The concentration of MLSS and MLVSS was stabilized at $14,668 \pm 1,864 \mathrm{mg} / \mathrm{L}$ and $10,874 \pm 1,477 \mathrm{mg} / \mathrm{L}$ with MLVSS/MLSS $\geq 0.74$ for MBR (Figure 2).

There was a high peak of MLSS and MLVSS during the days $15-20$ because there were high concentrations of COD and SS in the influent of POME. The MLSS and MLVSS values for AS were maintained at $6,590 \pm 640 \mathrm{mg} / \mathrm{L}$ and 4,461 $\pm 348 \mathrm{mg} / \mathrm{L}$ with the ratio of MLVSS/MLSS $\geq 0.68$ respectively. This was due to the high capacity of biomass retention by membrane module. The MLVSS/MLSS ratio of the MBR was higher than the AS which is known to be $0.5-0.8$ in most cases [9]. The relatively stable ratio of MLVSS to MLSS in the first period of operation implied that the amount of biomass and inorganic remainders constituted a dynamic balance [10]. The observed sludge yield value was calculated as the ratio between the VSS accumulated in the reactor and the cumulative COD removal. The sludge yield value in MBR was nearly $0.28 \mathrm{gVss} / \mathrm{gCOD}_{\text {rem }}$, which corresponded to $0.39 \mathrm{gCOD} / \mathrm{gCOD}_{\mathrm{rem}}$. The value in AS was about $3.04 \mathrm{gVss} / \mathrm{gCOD}_{\text {rem }}$ and corresponded to $4.31 \mathrm{gCOD} / \mathrm{gCOD}_{\text {rem }}$ (using a factor of $1.42 \mathrm{gCOD} / \mathrm{gVss}$ ). This result demonstrated the lower 10 times sludge yield value in MBR than in AS reducing excess sludge production in MBR. However, in the studied conditions of this MBR showed the higher 3 times value of sludge yield obtained than those reported in the literatures $[11,12]$.

The mean particle size distribution for both reactors was determined. It was found that in the MBR it showed a value of mean floc size of $20.05 \mu \mathrm{m}$, which was 3 times smaller than that of the AS reactor, $61.68 \mu \mathrm{m}$. The reason was probably due to different effect and levels of aeration inside each reactor. For the MBR, the air supply was higher than in the AS because it was necessary to minimize sludge accumulation. The recirculation of sludge during anoxic time in the MBR by the recycling pump may be induced by higher shear stress than in the AS system. This might destroy sludge particles [13]. The SVI values were about $80-90 \mathrm{~mL} / \mathrm{g}$ in the MBR and $120-150 \mathrm{~mL} / \mathrm{g}$ in the AS. These results showed

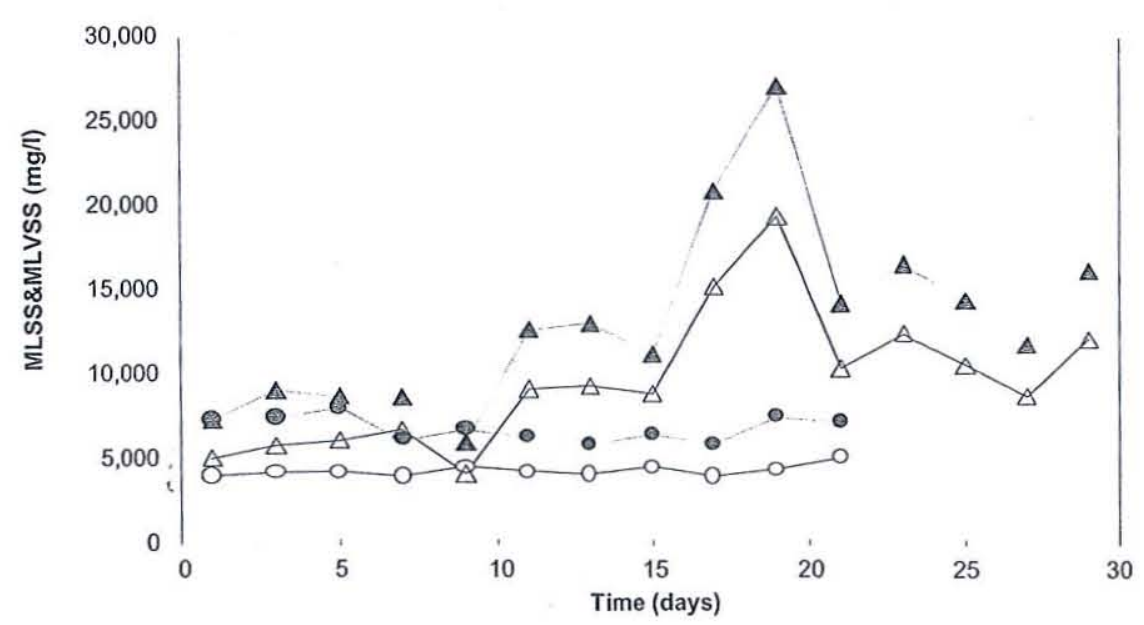

Figure 2 Comparison of MLSS\&MLVSS in two systems (Symbol; (Ө)AS-MLSS; (A) MBR-MLSS; (O) AS-MLVSS; ( $\triangle$ ) MBR-MLVSS) 
that the AS was bulking sludge. However, the small sludge particles in this MBR can enhance the decomposition of organic carbon and nitrogen, even given the complexity and variation of suspended solids and organic contents in term of COD and BOD of the inlet POME. Due to the nature of the MBR operating without sludge extraction, the endogenous decay process of sludge related and given lower biomass yields more than the AS system. The majority of microbial communities of both reactors were bacteria in floc form. But a different variety of microbial groups were observed in the MBR and AS, such as protozoa and metazoa, for each stage of the biological condition. In this work the microbial community in the MBR contained many free swimming cilia in all periods of operation, but only a few stalked ciliates. The AS system showed a high amount of diatom. The diatom genus in the AS was Navicula which is usually in high organic loading of wastewater [14].This result confirmed that the MBR became a high stability system in a short time.

\subsection{Efficiency of MBR and AS for Organic Carbon and Nitrogen Removal}

The concentration of COD and BOD in POME was an average of $2845 \pm 77 \mathrm{mg} / \mathrm{L}$ and $149 \pm 55 \mathrm{mg} /$
$\mathrm{L}$ during the course of operation. The COD/BOD ratio of influent was very high with values between 19 and 30. This indicates high content of non-biodegradable material. The fraction of soluble COD in the influent was an average $2845 \pm 77 \mathrm{mg} / \mathrm{L}$. As shown in Table 2, the POME characteristics had a large portion of TSS inducing a high content of organic matter with the value of color $201 \pm 44 \mathrm{SU}$. The removal efficiencies of the organics observed in this study is summarized in Table 2.

The COD removal occurred when the process reached a steady state after 18 days and 15 days respectively in the MBR and AS systems. The MBR showed a higher removal rate of COD, BOD and Turbidity of 1,2 and 3 times more than the AS. Table 2 summarizes the effectiveness of the MBR and AS systems in the treatment of POME. Figure 3 shows the concentration of COD in POME and the removal efficiency in the MBR and the AS systems. It found that the removal efficiency of COD and BOD of MBR were 69\% and $76 \%$, which was higher than those in the AS (COD and BOD removal of $54 \%, 48 \%$ respectively). In addition, the removal rate of COD and Oil and Grease in the MBR were very high but the AS decreased when the system was being fed with influent of high organic strength (in day 3 and day 11). This showed the benefit of

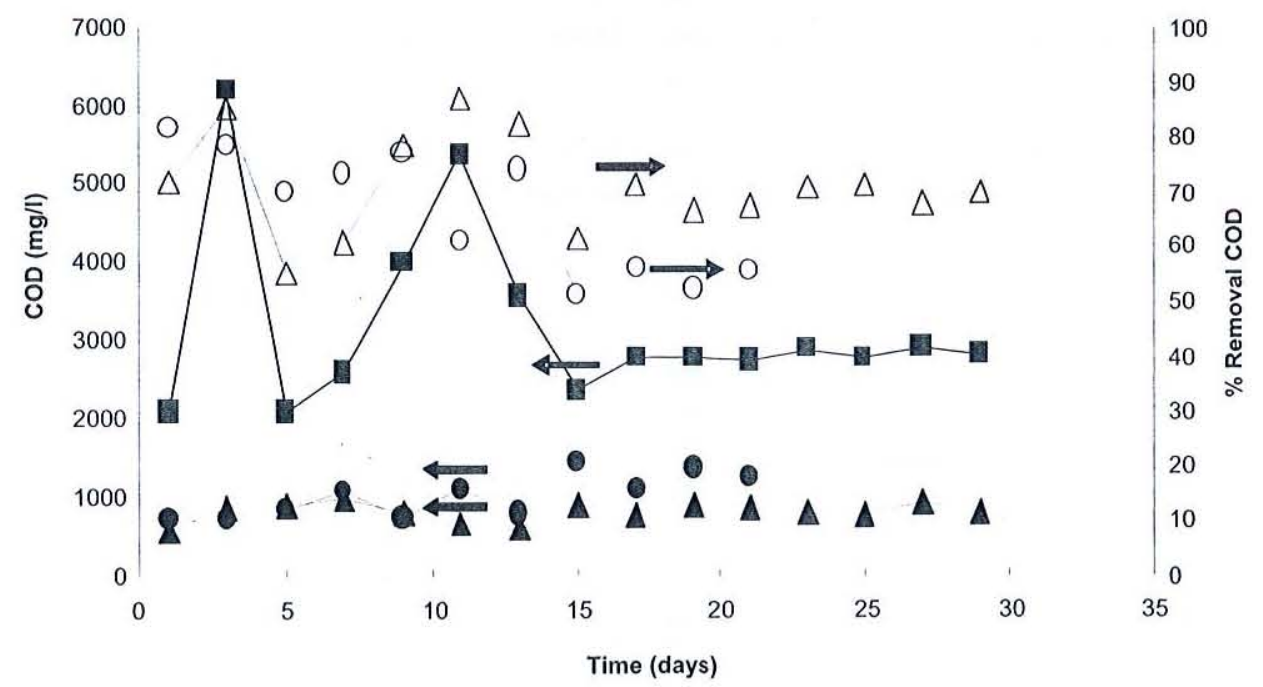

Figure 3 Comparison of COD concentrations and removal efficiencies of two systems. (Symbol: (圆) Influent; ( $)$ AS effluent; ( $\Delta$ ) MBR effluent; (O) AS COD removal; $(\triangle)$ MBR COD removal) 
membrane separation ăs it totally retains biomass containing high concentration and variety of the biomass community. The MBR can tolerate the variation of high organic and hydraulic loads. However, the quality of permeate from the MBR still remained light-brown in color, because small molecules of tannin caused a natural color, which was not completely eliminated by biological reaction and membrane separation using the pore size studied.

The residual turbidity was in the range of $2.2 \pm 0.8$ and $347 \pm 80 \mathrm{NTU}$ for the MBR and AS, high suspended solids, $1019 \pm 706 \mathrm{mg} / \mathrm{L}$, and still presented in the AS according to the capacity of sedimentation tank, to a high content of Oil and Grease at the same time of SS in the influent of POME.

The overall removal rate of TKN, $\mathrm{NH}_{3}{ }^{-} \mathrm{N}$ of MBR was twice as high compared with the AS system. These results indicated that the nitrogen compounds were mostly transformations and eliminated by the process of nitrification and denitrification. The concentrations of $\mathrm{NO}_{2}$ and $\mathrm{NO}_{3}$ were still remaining in the range of $13 \pm 10$ and of $32 \pm 23 \mathrm{mg} / \mathrm{L}$ for the MBR. In the $\mathrm{AS} \mathrm{NO}_{2}$ and $\mathrm{NO}_{3}$ concentrations were about $2 \pm 3$ and $11 \pm 6$ $\mathrm{mg} / \mathrm{L}$. This difference was caused by the concentration of dissolved oxygen (DO) limited in the AS $(1.10-1.30 \mathrm{mg} / \mathrm{L})$ for simultaneous conditions. More observation of dissolved oxygen in MBR was detected during the aerobic and anoxic phases and it was found that DO was about 5-7 mg/L, which confirmed the most suitable condition for getting nitrification and providing a good turbulence close to the membrane module. The conventional values of air flow rate in several $\mathrm{MBR}$ were reported in the range of $1-25 \mathrm{~m}^{3}$ of air $/ \mathrm{h} / \mathrm{m}^{2}$ of membrane [15-17] when it was compared with the value of air flow rate in this study, $3 \mathrm{~m}^{3}$ of air $/ \mathrm{h} / \mathrm{m}^{2}$ of membrane, using in the low range of air flow rate designed for energy consumption. The DO concentration in the MBR decreased slowly to $0.9 \mathrm{mg} / \mathrm{L}$ after stopping aeration for $1 \mathrm{~h}$ due to obstruction of microbial activity in MBR and long SRT, and high MLVSS [18]. Specific microbial activity of nitrification required sufficient oxygen as an electron acceptor. Although the dissolved oxygen concentration of the mix liquor is at a sufficient level to maintain an aerobic condition, inefficient oxygen transfer can be deriyed by increased fluid resistance due to the high MLVSS concentration and viscosity [19]. Thus the capacity of microbial decreased to capture the remaining DO and decreasing in the anoxic phase. Moreover, the quantity of $\mathrm{NO}_{3}$ concentration did not use it in the first priority as the electron acceptor. In this study MBR the occurrence of simultaneous nitrification and denitrification was also observed. The optimum condition for nitrogen removal was suggested by intermittently air flow rate with the maximum and minimum of dissolved oxygen between $2.0-2.5 \mathrm{mg} / \mathrm{L}$ and less than $0.4, \mathrm{mg} / \mathrm{L}$. [20]. The rate of energy consumption in both systems were about $0.12 \mathrm{~kW} \cdot \mathrm{h} / \mathrm{m}^{3}$ and $0.09 \mathrm{~kW} . \mathrm{h} /$ $\mathrm{m}^{3}$ for AS and MBR. The continuous aeration and return sludge mode played an important factors to be consumed a high energy in AS.

\subsection{Transmembrane Pressure Variation and Flux Production}

Change in transmembrane pressure (TMP) in the operation period of 29 days was investigated according to intermittent aeration (anoxic $2 \mathrm{~h} /$ aerobic $1 \mathrm{~h}$ ). These are shown in Figure 4. The working conditions of $10 \mathrm{~L} / \mathrm{min}$ of air supply and the permeate flux of $10 \mathrm{~L} / \mathrm{h} / \mathrm{m}^{2}$ were maintained.

Figure 4 showed the variation of TMP. The initial value of TMP was at 12 mbars. The evolution of TMP was studied and thus the fouling rate could be calculated in term of TMP/dt. It was found that the membrane fouling rate was $0.78 \mathrm{mbars} / \mathrm{d}$. For this fouling rate value the critical time for cleaning the membrane may be estimated. It will have nearly 600 days under slope value from Figure 4, supposing that no rapid fouling from biomass deposition takes place due to high air flow rate at $10 \mathrm{~L} / \mathrm{min}$ with a long relax time of $2 \mathrm{~h}$ for the membrane in the anoxic phase. The visual observation of membrane module showed the accumulation of suspended solids, oil and grease and biomass in gel layer. The gel layer plays a secondary membrane to reject the soluble COD fraction. As mentioned by [21]. They studied this and pointed out that raising the air flow from 2.0 to $4.0 \mathrm{~L} / \mathrm{min}$ only reduced the suction pressure rise by around $18 \%$ [22] 


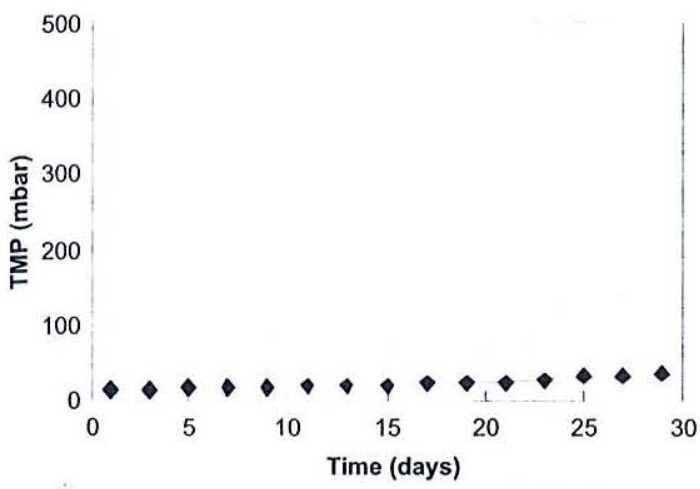

Figure 4 Variation of transmembrane pressure in MBR during first of 29 days

reported that intermittent suction and low transmembrane pressure helped to prevent irreversible damage to the membranes. However, this studied condition still faced with the slow increase of TMP with time because the contribution of small particles, macromolecules, soluble COD and the nature of POME causing membrane fouling while sludge deposition is also achieved [13]. It appeared an important to differentiate instantaneous permeate flux over average permeate flux per day in term of energy consumption as mentioned in above results. It was found that the intermittent aeration could reduce the unit of energy required more 6-8 times than in the operation with flux continuous of several reported MBR $\left(0.8 \mathrm{kw} . \mathrm{h} / \mathrm{m}^{3}\right.$ of industrial scale of MBR) [23-24]. However, it should be installed an anoxic unit prior the MBR for achieving nitrate removal.

\subsection{CONCLUSIONS}

This study compared the performances of an MBR and an AS in the treatment of palm oil mill effluent. The experimental units were fed with the same source of POME coming from a grease trap and anaerobic pond of a palm oil mill wastewater treatment plant. The operating conditions were set up and were favorable for biological treatment and with a high performance of filtration. The MBR was able to achieve better organic carbon and nitrogen removal efficiencies compared with the AS. To achieve more removal efficiency in both systems the recovery or removal of color will be investigated and implemented in next study.

Microscopic analysis of biomass in the MBR and AS systems showed that the characteristics of the MBR sludge was composed of a floc size, which was smaller 3 times than AS sludge. The composition of microbial community in the MBR after achieving a steady state condition presented a large portion of free swimming cilia, a few stalked ciliates and a few diatoms. However, the AS sludge consisted of a high number of diatoms, genus Navicula, indicating that the AS system was usually in a high organic loading condition.

\section{ACKNOWLEDGEMENTS}

This research was funded by Royal Thai Government year 2007 and supported by Faculty of Environmental Management, Department of Civil Engineering, Membrane Science and Technology Research Center (MSTRC) and Staff from Department of Micrology.

\section{REFERENCES}

[1] Ahmad, L.A., S. Bhatia, and S. Ismail. 2005. Membrane Treatment for Palm Oil Mill Effluent: Effect of Transmembrane Pressure and Crossflow Velocity. Desalination. 179: 245-255.

[2] Ma, A.N., C.S. Chow, C.K. John, A. Ibrahim, and Z. Isa. 2001. Palm Oil Mill Effluent a Survey. In Proceedings of the PORIM Regional Workshop on Palm Oil Mill Technology and Effluent Treatment. M.S. Thesis. Palm Oil Research Institute of Malaysia (PORIM) Serdang, Malaysia.

[3] Ahmad, L.A., F.M. Chong, S. Bhatia, and S. Ismail. 2006. Drinking Water Reclamation from Palm Oil Mill Effluent (POME) Using Membrane Technology. Desalination. 191: 35-44.

[4] Department of Industrial Work. 1997. Palm Oil Industry Environmental Management Manual. 1-6. 
[5] Winnen, H., T. Suidan, M. Scarpino, V.P. Wrenn, B. Cicek, N.V. Urbain, et al. 1995. Effectiveness of the Membrane Bioreactor in the Biodegradation of High Molecularweight Compounds. Wat Sci Tech. 34: 197203.

[6] Fan, X.J., V. Urbain, Y. Qian, and J. Manem. 1996. Nitrification and MBR for Municipal Wastewater Treatment. M.S. Thesis. Tsinghua University.

[7] Yeom, I.T., M.Y. Nah, and H.K. Ahn. 1999. Treatment of Household Wastewater Using an Intermittently Aerated Membrane Bioreactor. Desalination. 124: 193-204.

[8] APHA-AWWA-WEF. 1998. Standard Methods for the Examination of Water and Wastewater. $20^{\text {th }}$ ed. Washington DC, USA.

[9] Xing, C.H., X.H. Wena, Y. Qiana, and E. Tardieub. 2001. Microfiltration Membrane Coupled Bioreactor for Urban Wastewater Reclamation. Desalination. 141: 63-73.

[10] Khor, S.L., D.D. Sun, C.T. Hay, and J.O. Leckie. 2006. Comparison of Submerged Membrane Bioreactor in Different SRT Conditions. M.S. Thesis. Nanyang Technological University.

[11] Pollice, A., G. Laera, and M. Blonda. 2004. Biomass Growth and Activity in a Membrane Bioreactor with Complete Sludge Retention. Water Research. 38: 1799-1808.

[12] Masse A., M. Sperandio, and C. Cabassud. 2006. Comparison of Sludge Characteristics and Performance of a Submerged Membrane Bioreactor and an Activated Sludge Process at High Solid Retention Time. Water Research. 40: 2405-2415.

[13] Ma, C.B., N.Y. Lee, S.J. Park, H.C. Lee, H.S. Lee, S.I. Chang, et al. 2006. Correlation Between Dissolved Oxygen Concentration, Microbial Community and Membrane Permeability in a Membrane Bioreactor. Process Biochemistry. 41: 1165-1172.

[14] Mayure, T. 1994. Water Quality was Biological Indicating. http://www.tistr.or.th. html. (accessed 11 Mach 2008).

[15] Li, Y.-Z., Y.-L. He, Y.-H. Liu, S.-C. Yang, and G.-J. Zhang. 2005. Comparison of the Filtration Characteristics between Bio- logical Powdered Activated Carbon Sludge and Activated Sludge in Submerged Membrane Bioreactors. Desalination. 174: 305 314.

[16] Kim, H.-S., S. Takizawa, and S. Ohgaki. 2007. Application of Microfiltration Systems Coupled with Powdered Activated Carbon to River Water Treatment. Desalination. 202: 271-277.

[17] Hong, S.P, T.H. Bac, T.M. Tak, S. Hong, and A. Randall. 2002. Fouling Control in Activated Sludge Submerged Hollow Fiber Membrane Bioreactor. Desalination. 143: 219-228.

[18] Lim, B.S., B.C. Choi, S.W. Yu, and C.G. Lee. 2007. Effects of Operational Parameters on Aeration on/off Timein an Intermittent Aeration Membrane Bioreactor. Desalination. 202: 77-82.

[19] Han, S.S., T.-H. Bae, G.G. Jang, and T.M. Tak. 2005. Influence of Sludge Retention Time on Membrane Fouling and Bioactivities in Membrane Bioreactor System. Process Biochemistry. 40: 2393-2400.

[20] Yoo, H., K.H. Ahn, H.J. Lee, K.H. Lee, Y.J. Kwak, and K.G. Song. 1999. Nitrogen Removal from Synthetic Wastewater by Simultaneous Nitrification and Denitrification (SND) Via Nitrite in an Intermittently-aerated Reactor. Water Research. 33: 145-154.

[21] Wicaksana, F., G.A. Fane, and V. Chen. 2006. Fibre Movement Induced by Bubbling Using Submerged Hollow Fibre Membranes. J. Mem Sci. 271: 186-195.

[22] Krampe, J., and K. Krauth. 2001 Sequencing Batch Reactor with Submerged Hollow Fibre Membranes for The Biomass Separation. Wat Sci Tech. 43: 1953-199.

[23] Zheng, X., and J. Liu. 2006. Dyeing and Printing Wastewater Treatment Using a Membrane Bioreactor with a Gravity Drain. Desalination. 190: 277-286.

[24] Liu, H., C. Yang, W. Pu, and J. Zhang. 2008. Removal of Nitrogen from Wastewater for Reusing to Boiler Feed-water by an Anaerobic/Aerobic/Membrane Bioreactor. Chem. Eng J. 140: 122-129. 